\title{
Stem Cell Reviews and Reports Enters 16th Year of Publishing
}

\section{Mariusz Z. Ratajczak $^{1}$}

Published online: 7 January 2020

(C) Springer Science+Business Media, LLC, part of Springer Nature 2020

We enter the new 16th year of publishing Stem Cell Reviews and Reports being one of most read stem cell and regenerative medicine focused journals. We are pleased to thank the excellent work of our Section Editors, Editorial Board members, and dedicated reviewers. We accepted the best papers, and our impact factor increased to 4.697. Stem Cell Reviews and Reports covers a broad range of topics, including different aspects of stem cell biology and tissue/organ regeneration. The 5 most cited papers so far from last year are listed below [1-5].

Our journal is open not only to clear scientific progress, but also to new and challenging ideas as well as some controversies in the field. Paradigms in science change with time and, as Albert Einstein stated, "Blind belief in authority is the greatest enemy of truth" and as his countryman Max Planck said "One rule is important in science - only courageous people win". In stem cell biology there are still many doors to be opened in order to understand this fascinating cell system, and courageous young investigators are needed. In pursuing scientific truth it is also important to be critical and to keep in mind another famous saying from Albert Einstein "Anyone who has never made a mistake has never tried anything new" and one from Maria Sklodowska-Curie "I was thaught that the way of progress is neither swift or easy". Therefore, we encourage you to submit your best work and help establish our journal as the premier journal in this important field.

Taking into consideration the increasing number of submitted papers to SCRR, with this new year 2019 we are pleased to announce the recruitment of a new Section Editors - Prof. Suming Huang from the Pennsylvania State of University, Hershey, USA, who will be responsible for a section on cancerogenesis and stem cells in aging. He will work together with our other four respected section editors Drs. Tiziana Brevini, Giovanni Camussi, Henning Ulrich, Louis Pelus and Edward Scott to bring our journal to the next level of

Mariusz Z. Ratajczak

mariusz.ratajczak@louisville.edu

1 University of Louisville, Louisville, KY, USA excellence. This year we accepted 82 best papers and our acceptance rate is close to $20 \%$. We would also like to thank Prof. Zbigniew Darzynkiewicz from New York College of Medicine, who retired as Section Editor for a section on cancerogenesis and stem cells in aging for his dedicated work for our journal.

Because of our goal to struggle for excellence and an increasing number of submissions we also welcome 4 new Editorial Board members Drs. Marcin Moniuszko from Medical University of Bialystok, Poland, Yi Qiu from Pennstate University Hershey, USA, Torsten Tonn from Carl Gustav Carus University Dresden, Germany and Bing Xu from Xiamen University, Xiamen, P.R. China.

We are living in very exciting times of stem cell research and their potential application in the clinic. Hematopoietic stem cells (HSC) have been successfully employed for 50 years in hematological transplantations. The successful clinical application of monopotent HSCs is widely understood to have helped establish the rationale for the development of stem cell therapies and regenerative medicine. Therefore, widely understood regenerative medicine is looking for a pluripotent/multipotent stem cell able to differentiate across germ layers and be safely employed in therapy. Unfortunately, with the exception of HSC for hematological applications, the current clinical results with adult stem cells are still somewhat not fully satisfactory. Interesting clinical effects with mesenchymal stem cells in regeneration of damaged organs are related to soluble factors and macrovesicles secreted by these cells. Furthermore, the potential clinical applications of the more primitive induced pluripotent stem cells (iPSCs) have so far been discouraging, as both have exhibited several problems, including genomic instability, a risk of teratoma formation, and the possibility of rejection. Moreover, the current results for clinical applications of iPSCs in patients have demonstrated only paracrine effects in therapy and no contribution of these cells to damaged organs. This all suggests a risk of an approaching twilight for the clinical application of iPSCs, unless some strategies will be developed to avoid these limitations. Therefore, more work is needed in this promising area. We need to better understand the molecular 
mechanisms involved in regulating stem cell pluripotency and differentiation. Evidence indicates that non-coding mRNA and miRNA are substantial components of regulatory networks in early development stem cells. We also need to find out if adult tissues contain some very rare early development stem cells - postulated since many years by several investigators.

Going forward, Stem Cell Reviews and Reports will continue to publish the latest discoveries and to entertain challenging and provocative ideas. As I mentioned above we encourage you to submit your best work and help establish our journal as the premier journal in this important field.

\section{References}

1. Zhang M, Jia L, Zhen Y (2019). circRNA expression profiles in human bone marrow stem cells undergoing osteoblast differentiation. Stem Cell Reviews and Reports, 15, 126-138.
2. Golchin, A., \& Farahany, T. Z. (2019). Biological products: Cellular therapy and FDA approved products. Stem Cell Reviews and Reports, 15, 166-175.

3. Acosta, S. A., Lee, J. Y., Nguyen, H., Kaneko, Y., \& Borlongan, C. V. (2019). Endothelial progenitor cells modulate inflammationassociated stroke Vasculome. Stem Cell Reviews and Reports, 15, 256-275.

4. Tahmasebi, S., Elahi, R., \& Esmaeilzadeh, A. (2019). Solid tumors challenges and new insights of CAR T cell engineering. Stem Cell Reviews and Reports, 15, 619-636.

5. Borgohain, M. P., Haridhasapavalan, K. K., Dey, C., Adhikari, P., \& Thummer, R. P. (2019). An Insight into DNA-free Reprogramming Approaches to Generate Integration-free Induced Pluripotent Stem Cells for Prospective Biomedical Applications. Stem Cell Reviews and Reports, 15, 286-313.

Publisher's Note Springer Nature remains neutral with regard to jurisdictional claims in published maps and institutional affiliations. 